\title{
Added-Value utility formulation in palm oil supply chain based on risk, investment and technology
}

\author{
Syarif Hidayat", Nunung Nurhasanah \\ Industrial Engineering Department, The University Al Azhar Indonesia, Jakarta, Indonesia \\ Email address: \\ syarif_hidayat@uai.ac.id (S. Hidayat), nunungnurhasanah@uai.ac.id (N. Nurhasanah)
}

\section{To cite this article:}

Syarif Hidayat, Nunung Nurhasanah. Added-Value Utility Formulation in Palm Oil Supply Chain Based on Risk, Investment and Technology. International Journal of Business and Economics Research. Special Issue: Supply Chain Management: Its Theory and Applications. Vol. 3, No. 6-1, 2014, pp. 57-64. doi: 10.11648/j.ijber.s.2014030601.19

\begin{abstract}
In palm oil supply chain (POSC) the operational risk, investment and technology levels between the actors may not be proportionately rewarded by the same levels of added value. Each actor will attempt to obtain the highest reward. However, each actor must consider the level of added-value obtained by other actors so as to maintain the fair balance in the overall supply chain profitability. Otherwise any of the least profitable actor will withdraw itself from the supply chain and the supply chain will collapse. In this study the authors proposed a formula to calculate the utility function based added-value for each of the actors in the POSC. The utility function is a formula based on the risk, investment and technology levels of each of the POSC actors. Permutation of the three factors was used while seeking their combination that give the highest utility function added-value. To optimize the added-value distribution between the agents the concept of stakeholder dialogue was used. This research is important because the developed models offer a workable algorithm to seek optimum weight level of underlying factors while calculating utility added-value that satisfy the POSC as a whole. Agent-based modeling approach was used for this purpose to facilitate the negotiation between all actors to reach the balanced added-values. Netlogo software was used in developing the models. The proposed utility function model provided the means to find the weight values, while the optimization model proved to be practical to calculate the expected negotiated prices between all the actors. Application of the models to other types of commodity and different supply chain model will need some adjustments in the calculation.
\end{abstract}

Keywords: Added-Value, Palm Oil Supply Chain, Permutation, Agent Based Modeling, Netlogo Software

\section{Introduction}

In a supply chain interdependent companies operate in sequence and cooperate in handling, improving and controlling the flows of goods, money and information. It begins with the supplier in the upstream and goes all the way downstream until the end consumers $([1,2])$. The principal roles of the supply chain is to add value to the products by moving them from one to another location, or to perform the modification processes [3]. The value adding processes may be applied to the quality, costs, delivery activities, flexibilities in sending the products, and innovations [4].

\subsection{Palm Oil Supply Chain}

One of the most important supply chains in Indonesia is the palm oil supply chain (POSC). Export of palm oil and its derivatives has always been increasing. In 2010 the export value was USD 15,6 billions, which has shown an increase of
$34,6 \%$ compared to 2009 . The export tax was US\$ 2,8 billion [5]. This value came second only to oil export. Figure 1 shows the 6 actors in the POSC. The smallholder farmers sell their fresh fruit bunch (FFB) to CPO Factory through traders. CPO Factory converts the FFB into crude palm oil (CPO). CPO is sold to the refinery, who converts CPO into frying oil and sends the product to the distributors. Although $\mathrm{CPO}$ can be converted into many types of popular consumer products, for simplicity in this study only frying oil refinery is discussed. The distributors subsequently sell them to the consumers. The farmers as a group supply the required FFB raw materials to the CPO factory through the traders. This is required to ensure the consistent quantitative operating levels along the POSC from the upstream to the downstream.

The business scale of each of the POSC actor is different from each other. The risks faced by each actor are different in type and level. The investment as well as the technology employed by each actor is also different in level. These three factors influence the capacity and the opportunity to create 
added value in each of the actors. The sum of the added value created by each actor produces the total added value for overall supply chain.

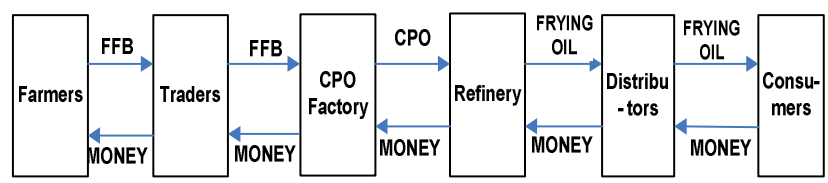

Figure 1. Palm oil supply chain actors

Due to the monopsonistic market conditions palm oil farmers bargaining power was low. [6] reported the sad conditions about small farmers suffering from low productivity compared to very high profit per hectare for the large estates, the low accessability to financial and technical supports, and lacking in representation in the decision making processes. [7] described the low prices of FFB by the farmers despite their high risks.

The objective of this study is to design a utility added value model based on the level and weight of the risks, investment, and the technology faced or employed by the POSC actors. To achieve this objective some theories, methodologies, and an alorithm are utilized.

\subsection{Theories Used in the Study}

The first theory is about added value. Added value may be defined as the incremental value to a commodity as it undergoes processing in the production stream [8]. [9] defined added value as the "difference between output value and the input costs". Added value concept is the increase in the value due to the growth of the value as functional input is affected to the commodity. Functional input is the treatment and services that causes increments in the utility and the value of the commodity [10]. Added value is the main motivation for the establishment and the growth of an enterprise. Without this no investor or businessman is willing to invest in or nurture a business. This kind of motive is the strongest one that push a person or an organization to get involved in supply chain [11]. [12] mentioned that the unfair cost and benefit distribution along an agroindustry supply chain will endanger its survival, as it hampers the efforts to modernize the agriculture and subsequently it will hamper the growth of the industry. The motives for the investor or the businessman to engage in any enterprise including the agroindustry is the fair and just arrangement of risk and benefit [1].

Added value formula is written as follows [13]:

$$
\begin{gathered}
\Pi=\mathrm{TR}-\mathrm{TC} \\
\mathrm{TR}=\mathrm{P} * \mathrm{Q} \\
\mathrm{TC}=\mathrm{TFC}+\mathrm{TVC}
\end{gathered}
$$

where

$\Pi=$ profit $=$ added value

$\mathrm{TR}=$ total revenue

$\mathrm{P}=$ price per unit
$\mathrm{Q}=$ quantity sold

$\mathrm{TC}=$ total cost

$\mathrm{TFC}=$ total fixed cost

$\mathrm{TVC}=$ total variable cost

The second theory is about negotiation behavior between POSC actors. Actors will need to interact very closely to obtain either raw materials or sell their products. They need to do this at the most efficient and economical manners to maintain their continuous financial objectives. They have to consider supply chain factors such as inbound lead times \& associated variability, supply chain risk, protection of supply \& logistics costs as well as risk \& inventory costs [14]. During negotiation stages there are additional factors that need to be considered [15]. They are : the level of dependence perceived by each negotiator (both customers and suppliers were measured); the cooperative orientation of each negotiator (both customers and suppliers are measured); the cooperative orientation of each negotiator; the level of coercion implemented in the negotiation; and the level of contract formality implemented in the negotiation. In this study, the negotiation will consider the concept of fairness as introduced by stakeholder dialogue concept. Basically the method is a structured discussions between the representatives of business partners or companies [16].

The third theory discussed in this study is the utility formulation to describe added value calculation. The selling prices are negotiated between the actors until each actor reaches a satisfactory value, which is ruled by the levels of optimum added value utility. The concept about the utility function is that all of the tangible and intangible outputs of various business processes, represent inputs into the intrinsic satisfactions, or else they represent goods and services that add to the stock of wealth available for the production of future satisfactions of the actor [17]. With satisfaction the author is referring to the optimization of the added value obtained from the business negotiation in the POSC. In this research the utility function is written in an exponential format.

\section{Methods}

In line with the objective, this study is organized into several parts as follows: (1) identification of the actors, with relevant risk, investment and technology factors in the POSC, (2) formulation of the added values in the POSC, (3) formulation of the negotiation behavior in the POSC, (4) formulation of permutation and iterative algorithm using the three factors, and (5) development of the solution models using Agent Based approach and Netlogo software.

\subsection{Identification of POSC Actors, Risk, Investment and Technology Levels}

All information and data needed for this study are obtained and identified from recent literatures and by interviewing relevant managers in the palm oil industries. Risk, investment and technology levels for each actor are obtained from replies to questionnaires, as well as from secondary 
resources. Most quantitative results are taken from the author's previous study in the POSC [18]. Calculation of input material quantities, investment and maintenance costs follow modified Hayami Method. The technology levels are defined as the combination of their sophistication, operation personnel costs, and maintenance costs. Each are given a weight factor, and later normalized to obtain a global score.

\subsection{Formulation of added value for the POSC}

Following [19] by common sense it was assumed that if the risk is higher then the added value should be higher. Likewise, the higher the investment level and the technology employed, the higher the added value. The level of risk, investment, and technology will never be zero. Nowadays for any real business there are always risk faced by the industry, need for investment, and some technology, although with some differences in their level. An exponential utility function is the best representation of this logic. This assumption is written as a functional exponential utility formula for added value shown in (4).

$$
\begin{aligned}
\mathrm{AV} & =\mathrm{f}(\text { investment, risk, technology) } \\
& =\alpha \mathrm{e}^{\left(\mathrm{w} 1 \mathrm{i}^{*} \mathrm{x} 1 \mathrm{i}+\mathrm{w} 2 \mathrm{i}^{*} \mathrm{x} 2 \mathrm{i}+\mathrm{w} 3 \mathrm{i}^{*} \mathrm{x} 3 \mathrm{i}\right) \alpha}
\end{aligned}
$$

where :

$\mathrm{AV}=$ Utility based added value

$\alpha=$ variable coefficient

$\mathrm{w} 1 \mathrm{i}=$ risk weight level for $\mathrm{i}$-th POSC actor

$\mathrm{x} 1 \mathrm{i}=$ risk score for $\mathrm{i}$-th POSC actor

$w 2 i=$ investment weight level for $i$-th POSC actor

$\mathrm{x} 2 \mathrm{i}=$ investment score for $\mathrm{i}$-th POSC actor

$\mathrm{w} 3 \mathrm{i}=$ technology weight level for $\mathrm{i}$-th POSC actor

$\mathrm{x} 3 \mathrm{i}=$ technology score for $\mathrm{i}$-th POSC actor

$i=1,2,3,4,5,6$ the actors of the POSC, namely the group of farmers, traders, CPO factory, Frying oil refinery, distributors and the consumers, respectively.

Subject to the constraints:

$$
\begin{gathered}
0<w 1 i, w 2 i, w 3 i<1 \\
w 1 i+w 2 i+w 3 i=1
\end{gathered}
$$

The total sum of weights should be equal to 1 , while the weight levels for risk, investment and technology are defined to be less than 1 . The value for $\alpha$ from previous research was selected at 2.0 as this value provides sufficient visibility of the graph movement.

In this study, the scores are obtained from the field. It is the values of the weight level that we need to find that give the optimum AV.

\subsection{Identification of Negotiation Behavior}

In agroindustry supply chain the business aims at maintaining supply continuity and improve the raw materials quality while balancing the financial interests for each actor. The farmers want to get the highest price for their crops, but the traders and factories demand the lowest cost for quality products [20]. Figure 2 shows a flowchart how the negotiation process is conducted between farmers and traders. This diagram represent the application of stakeholder dialogue approach by checking if the profit obtained by each POSC actor is higher than the expected gain, and if the gain is higher than the overall POSC gain. Initially the selling price is set, and the gains of both negotiating parties are calculated. The price is increased or lowered, until the gains are acceptable by both negotiating partners. The process is continued between two consecutive actors along the POSC.

Now we need to find the negotiated selling prices between two consecutive POSC actors which are acceptable to both parties, i.e. both are happy as the utility function reaches optimum value. This is achieved when the weight level of risk, investment and technology are adjusted in trial-anderror iterative fashion between both parties and the value of the utility function is calculated. The process is described in the next paragraph.

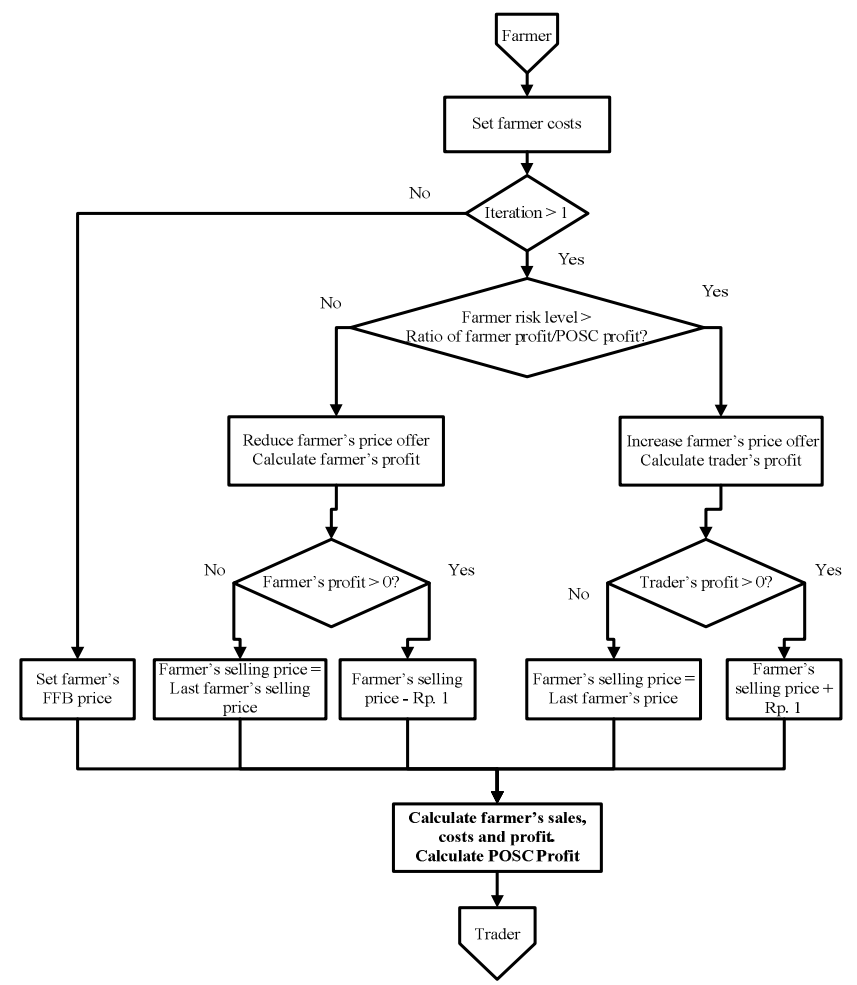

Figure 2. Business negotiation process diagram between the farmer and the trader.

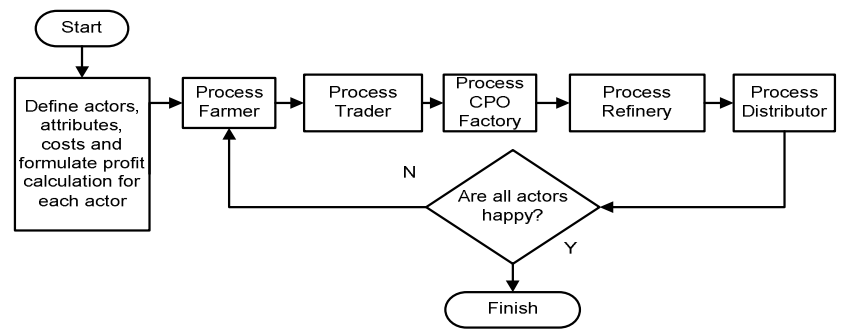

Figure 3. Overall negotiation process in the POSC.

Bear in mind that the model is controlled to maintain a satisfactory level of overall POSC profitability as shown in 
Figure 3. The negotiation process will only stop when individual actor has reached satisfactory added value utility level, therefore the overall POSC profitability is sustained. The overall processes are then translated into Netlogo software program.

\subsection{Formulation of Permutation and Iterative Algorithm}

While we have 3 factors to consider i.e. the weight levels of risks, investments and technology for all five of the supply chain actors, we use mathematical permutation to seek the combinations of the factors which will provide the highest added value of the POSC business. We start with assigning the lowest possible value for one factor $(0.001)$ and increase this value step-by-step by 0.001 until it to reach the highest value of 0.998 . For the second factor we started with the lowest value of 0.001 , keep it at this level, while to the third factor we assign the highest value of 0.998 because have already assigned the initial value of 0.001 and 0.001 for the first two factors, and that the sum must be equal to one.

Using the Netlogo modelling language we work out an iteration in the following fashion. A represents the values for risk factor; $\mathrm{B}$ represents the values for investment factor, and $\mathrm{C}$ represents the values for technology factor. $\mathrm{ABC}$ means we started the values of risk factor from 0.001 . The value $(=\mathrm{A})$ is incremented with 0.001 gradually until it reaches 0.998 . The value for investment $(=\mathrm{B})$ is kept constant at 0.001 . The technology factor, the third $(=\mathrm{C})$ was started at 0.998 , decreased by 0.001 until it reaches 0.001 . Next, the value A is increased to 0.002 , B stays at 0.001 and C starts at 0.997 . The process is then repeated. This is repeated until A starts at $0.998, \mathrm{~B}$ at 0.001 and $\mathrm{C}$ at 0.001 .

This procedure is repeated for the other 5 permutation namely $\mathrm{ACB}, \mathrm{BAC}, \mathrm{BCA}, \mathrm{CAB}$ and $\mathrm{CBA}$ with the corresponding changes in each iteration. Table 1 shows the iteration steps for the permutation. We regard each iteration as the realization of one negotiation cycle between the POSC actors. In one negotiation cycle we adjust the levels of weight risk, investment and technology and calculate the related value of the utility function.

Table 1. Iteration steps

\begin{tabular}{|c|c|c|c|c|c|c|c|c|c|}
\hline & & $1 \mathrm{st}$ & 2nd & 3rd & 4th & 5 th & 6th & 7th & End value \\
\hline \multicolumn{10}{|c|}{ Iteration for $A B C$} \\
\hline Risk & $\mathrm{A}$ & 0.001 & 0.002 & 0.003 & 0.004 & 0.005 & 0.006 & 0.007 & 0.998 \\
\hline Investment & $\mathrm{B}$ & 0.001 & 0.001 & 0.001 & 0.001 & 0.001 & 0.001 & 0.001 & 0.001 \\
\hline \multicolumn{10}{|c|}{ Iteration for $A C B$} \\
\hline Risk & A & 0.001 & 0.002 & 0.003 & 0.004 & 0.005 & 0.006 & 0.007 & 0.998 \\
\hline Investment & B & 0.998 & 0.997 & 0.996 & 0.995 & 0.994 & 0.993 & 0.992 & 0.001 \\
\hline Technology & $\mathrm{C}$ & 0.001 & 0.001 & 0.001 & 0.001 & 0.001 & 0.001 & 0.001 & 0.001 \\
\hline \multicolumn{10}{|c|}{ Iteration for $B A C$} \\
\hline Risk & $\mathrm{A}$ & 0.001 & 0.001 & 0.001 & 0.001 & 0.001 & 0.001 & 0.001 & 0.001 \\
\hline Investment & B & 0.001 & 0.002 & 0.003 & 0.004 & 0.005 & 0.006 & 0.007 & 0.998 \\
\hline Technology & $\mathrm{C}$ & 0.998 & 0.997 & 0.996 & 0.995 & 0.994 & 0.993 & 0.992 & 0.001 \\
\hline \multicolumn{10}{|c|}{ Iteration for $B C A$} \\
\hline Risk & A & 0.998 & 0.997 & 0.996 & 0.995 & 0.994 & 0.993 & 0.992 & 0.001 \\
\hline Investment & B & 0.001 & 0.002 & 0.003 & 0.004 & 0.005 & 0.006 & 0.007 & 0.998 \\
\hline Technology & $\mathrm{C}$ & 0.001 & 0.001 & 0.001 & 0.001 & 0.001 & 0.001 & 0.001 & 0.001 \\
\hline \multicolumn{10}{|c|}{ Iteration for $C A B$} \\
\hline Risk & A & 0.001 & 0.001 & 0.001 & 0.001 & 0.001 & 0.001 & 0.001 & 0.001 \\
\hline Investment & B & 0.998 & 0.997 & 0.996 & 0.995 & 0.994 & 0.993 & 0.992 & 0.001 \\
\hline Technology & $\mathrm{C}$ & 0.001 & 0.002 & 0.003 & 0.004 & 0.005 & 0.006 & 0.007 & 0.998 \\
\hline \multicolumn{10}{|c|}{ Iteration for $C B A$} \\
\hline Risk & $\mathrm{A}$ & 0.998 & 0.997 & 0.996 & 0.995 & 0.994 & 0.993 & 0.992 & 0.001 \\
\hline Investment & B & 0.001 & 0.001 & 0.001 & 0.001 & 0.001 & 0.001 & 0.001 & 0.001 \\
\hline Technology & $\mathrm{C}$ & 0.001 & 0.002 & 0.003 & 0.004 & 0.005 & 0.006 & 0.007 & 0.998 \\
\hline
\end{tabular}

\subsection{Development of Netlogo Agent Based Modeling}

Agent-based modeling approach is used for this purpose as it provided the best means to identify and study the supply chain actors (or agents) business and decision making behaviors. The agent-based approach facilitates the interaction between all the POSC actors with the characteristics of autonomy, social interaction, reactive and pro-active behaviours [21].

Netlogo open-source programming software is used to develop the agent-based program due to its vast modeling facilities, easy availability, and continuous development by the diverse user communities. The programming language is flexible and facilitate appropriate algorithm coding. It also has the facility to write the numerical calculation output in an excel-like format [22].

Two Netlogo models were developed, i.e. Utility model and the Optimization model. The Utility model is used to obtain the weight levels of risk, investment and technology that give the optimum utility or added value. For each permutation described in paragraph 2.4 , say ABC, the Utility model calculates the utility based added value for a combination of score and weight level of risk, investment and technology for all 5 POSC actors. While the weight levels are being changed in the iteration, a plot is printed in the output. The result for the complete iteration is a repetitive 
exponential graph as shown in Figure 4 and Figure 5.

To obtain the optimum level in trial-and-error iterative fashion we plot the graph of one permutation, say $\mathrm{ABC}$, and plot another permutation, say $\mathrm{ACB}$, side by side, and find where the two graphs intersect. At this intersection we consider that the risk, investment, and technology level meet the optimum utility added value for all 5 POSC actors.

These weight levels then are entered into the Netlogo Optimization model to find the selling prices and the individual added values for each of the POSC actors. In this Optimization model, the selling prices undergo the iterative negotiation process again to achieve the most acceptable added value level, following the logic shown in Figure 2. The Optimization model is written to facilitate the calculation following the process described in paragraph 2.4 .

\section{Results and Discussion}

\subsection{The actors in the POSC}

The CPO factory in the study has a processing capacity of 30 tons of FFB per hour. To operate for a year (working 300 days per year and 20 hours per day) the factory needed $180.000 .000 \mathrm{~kg}$ of FFB). This amount of FFB is produced by a palm oil estate of 3.032 hectares. Assuming that one farmer owns 2 hectares, then 1.516 farmers are involved in producing the required FFB. However, the CPO factory is supplied $50 \%$ of its $\mathrm{FFB}$ requirement from its own palm oil estate. The respective operating maintenance costs, yields, and added values were calculated using these capacity and respective amount of FFB needs, to obtain corresponding value-added or utility values.

\subsection{Investment, Risk and Technology Levels}

The scores of risk, investment and technology levels for each actor in the POSC, i.e. $x 1 i, x 2 i$ and $x 3 i$, were obtained from the interviews with the selected respondents in previous research [18]. Identified risks are shown in Table 2. The data is processed using Fuzzy Analytical Hierarchy Processing (FAHP) to give the final scores shown on the first row of Table 3. The investment levels were identified from each of the financial reports, further processed using modified Hayami method [18] and normalized to result in the scores shown on Tabel 3. The technology levels were defined as the combination of their values, sophistication, and maintenance costs. Each were given a weight factors, and later normalized to obtain a global score.

Table 2. Identified risks and their final scores

\begin{tabular}{|c|c|c|c|c|c|c|c|}
\hline \multirow[b]{2}{*}{ Risk Type } & \multicolumn{7}{|c|}{ Supply Chain Actor } \\
\hline & Farmer & Trader & CPO Fet & Refinery & Distributor & Consumer & Score \\
\hline Price & 0.119 & 0.145 & 0.045 & 0.076 & 0.137 & 0.221 & 0.108 \\
\hline Supply & 0.082 & 0.198 & 0.208 & 0.197 & 0.146 & 0.087 & 0.152 \\
\hline Transportation & 0.037 & 0.074 & 0.035 & 0.043 & 0.141 & 0.087 & 0.058 \\
\hline Information & 0.050 & 0.062 & 0.044 & 0.046 & 0.049 & 0.057 & 0.050 \\
\hline Policy & 0.037 & 0.040 & 0.034 & 0.031 & 0.048 & 0.057 & 0.039 \\
\hline Market & 0.041 & 0.154 & 0.081 & 0.082 & 0.166 & 0.081 & 0.121 \\
\hline Warehousing & 0.140 & 0.057 & 0.032 & 0.054 & 0.066 & 0.075 & 0.045 \\
\hline Production & 0.100 & 0.037 & 0.138 & 0.156 & 0.037 & 0.060 & 0.098 \\
\hline Environment & 0.072 & 0.025 & 0.060 & 0.054 & 0.031 & 0.061 & 0.054 \\
\hline Quality & 0.166 & 0.065 & 0.138 & 0.156 & 0.066 & 0.129 & 0.129 \\
\hline Partnership & 0.093 & 0.116 & 0.067 & 0.046 & 0.090 & 0.051 & 0.081 \\
\hline Technology & 0.059 & 0.028 & 0.118 & 0.078 & 0.023 & 0.033 & 0.064 \\
\hline
\end{tabular}

Table 3. POSC actors risk, investment and technology levels

\begin{tabular}{llllll}
\hline Variable & Farmer & Trader & CPO Factory & Refinery & Distributor \\
Risk & 0.355 & 0.124 & 0.224 & 0.193 & 0.103 \\
Investment & 0.01 & 0.028 & 1.313 & 1.953 & 0.04 \\
Technology & 0.104 & 0.224 & 2.07 & 0.822 & 0.316 \\
\hline
\end{tabular}

The Netlogo negotiation process model shows output graphs as depicted in Figure 4, 5 and 6. They show the movement of the utility added value figures following the changes of each iteration as described in paragraph 2.5. The vertical axis represent the movement of the added value (in percentage of maximum value) for each actor until the optimum stable selling price for each product is obtained. It is obvious that the selling prices for the refinery and the distributor are decreasing, while the selling prices of CPO factory, farmers and the traders are increasing following the relevant added values.

\subsection{Calculation of Maximum Utility Formula}

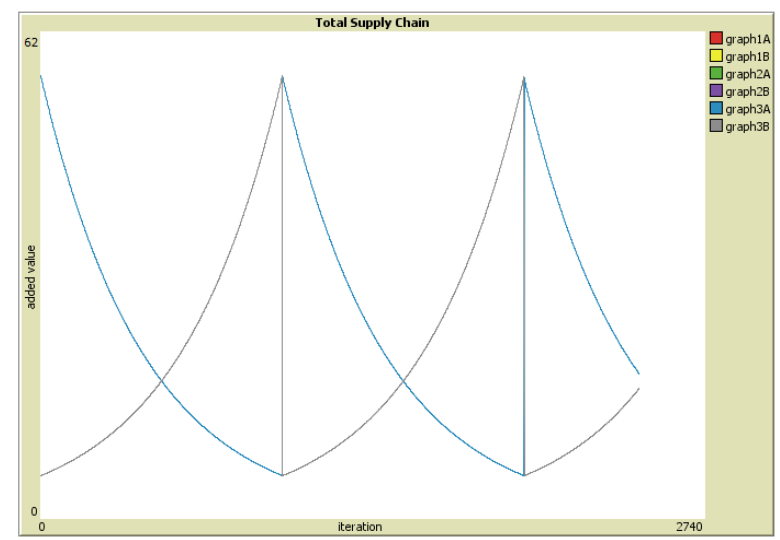

Figure 4. The Netlogo output after the negotiation cycle. 
The Utility function described in paragraph 2.2. will look for the optimal values for the variation values for the risk, investment, and technology.

Figures 4, 5 and 6 show the output "world model" in Netlogo showing the actors added value for each incremental iteration. Figure 4 shows the initial condition after running the iteration twice as the realization of stakeholder dialogue procedure. Figure 5 show the result after 5 cycles of the iteration, while Figure 6 shows the final condition after the permutation iteration was completed. The highest optimum values following the process described in paragraph 2.4 are shown in Table 4. The table shows that the farmers and traders added values are increased by the end of the negotiation cycle.

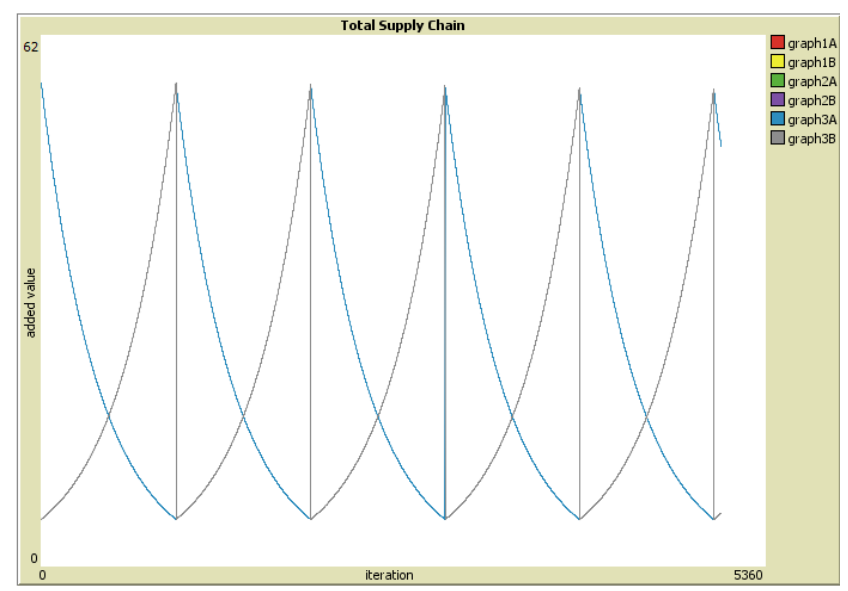

Figure 5. The Netlogo output after the negotiation cycle.

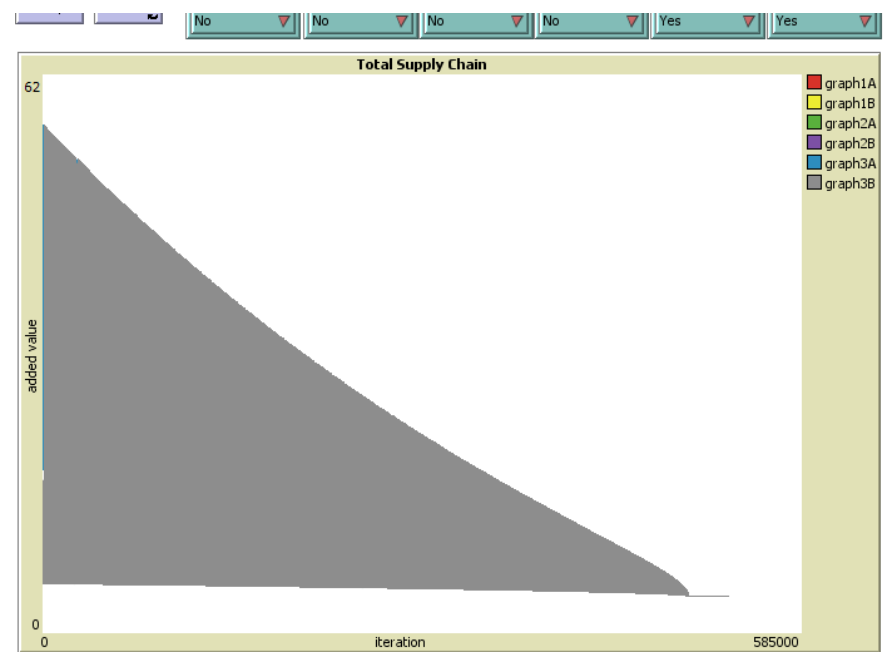

Figure 6. The Netlogo output after the negotiation cycle.

Table 4 shows the highest crosspoint between two utility graphs while running the Utility Netlogo Model. Permutations $\mathrm{CAB}$ and $\mathrm{CBA}$ provided the result.

Table 4. Added value for each iteration

\begin{tabular}{|c|c|c|c|c|c|c|c|c|}
\hline \multirow[b]{2}{*}{ Iteration } & \multicolumn{4}{|c|}{ CAB Permutation } & \multicolumn{4}{|c|}{ CBA Permutation } \\
\hline & W1 & W2 & W3 & Utility & W1 & W2 & W3 & Utility \\
\hline 1 & 1 & 998 & 1 & 56.382 & 998 & 1 & 1 & 5.442 \\
\hline 2 & 2 & 997 & 1 & 56.250 & 997 & 2 & 1 & 5.455 \\
\hline 3 & 3 & 996 & 1 & 56.118 & 996 & 3 & 1 & 5.468 \\
\hline 4 & 4 & 995 & 1 & 55.987 & 995 & 4 & 1 & 5.481 \\
\hline 5 & 5 & 994 & 1 & 55.856 & 994 & 5 & 1 & 5.494 \\
\hline 6 & 6 & 993 & 1 & 55.725 & 993 & 6 & 1 & 5.506 \\
\hline 7 & 7 & 992 & 1 & 55.594 & 992 & 7 & 1 & 5.519 \\
\hline 8 & 8 & 991 & 1 & 55.464 & 991 & 8 & 1 & 5.532 \\
\hline 9 & 9 & 990 & 1 & 55.334 & 990 & 9 & 1 & 5.545 \\
\hline 10 & 10 & 989 & 1 & 55.205 & 989 & 10 & 1 & 5.558 \\
\hline 11 & 11 & 988 & 1 & 55.075 & 988 & 11 & 1 & 5.571 \\
\hline 12 & 12 & 987 & 1 & 54.946 & 987 & 12 & 1 & 5.584 \\
\hline 496 & 496 & 503 & 1 & 17.661 & 503 & 496 & 1 & 17.374 \\
\hline 497 & 497 & 502 & 1 & 17.620 & 502 & 497 & 1 & 17.415 \\
\hline 498 & 498 & 501 & 1 & 17.579 & 501 & 498 & 1 & 17.455 \\
\hline 499 & 499 & 500 & 1 & 17.538 & 500 & 499 & 1 & 17.496 \\
\hline 500 & 500 & 499 & 1 & 17.496 & 499 & 500 & 1 & 17.538 \\
\hline 501 & 501 & 498 & 1 & 17.455 & 498 & 501 & 1 & 17.579 \\
\hline 502 & 502 & 497 & 1 & 17.415 & 497 & 502 & 1 & 17.620 \\
\hline 503 & 503 & 496 & 1 & 17.374 & 496 & 503 & 1 & 17.661 \\
\hline 504 & 504 & 495 & 1 & 17.333 & 495 & 504 & 1 & 17.703 \\
\hline
\end{tabular}


The highest utility added value was 17.538 , obtained for iteration 499 , with risk weight factor $\mathrm{w} 1=499$, investment weight factor $\mathrm{w} 2=500$ and technology weight factor $\mathrm{w} 3=1$. These weight factors apply to all 5 POSC actors.

\subsection{Calculation of Maximum Selling Prices}

The weight factor values from paragraph 3.3. were then entered into the Optimization Netlogo Model to obtain the individual product prices and added values for the respective weight levels. Figure 7 shows the "world output" of the Netlogo model after the negotiation cycle was completed at iteration 720 where the iteration was stopped. The weight levels for the risk, investment and the technology are shown at the top. The selling prices changes in each iteration are shown. The figure shows the calculated "should be" prices and the relevant achieved added value (in ratio format) at every iteration of price changes.

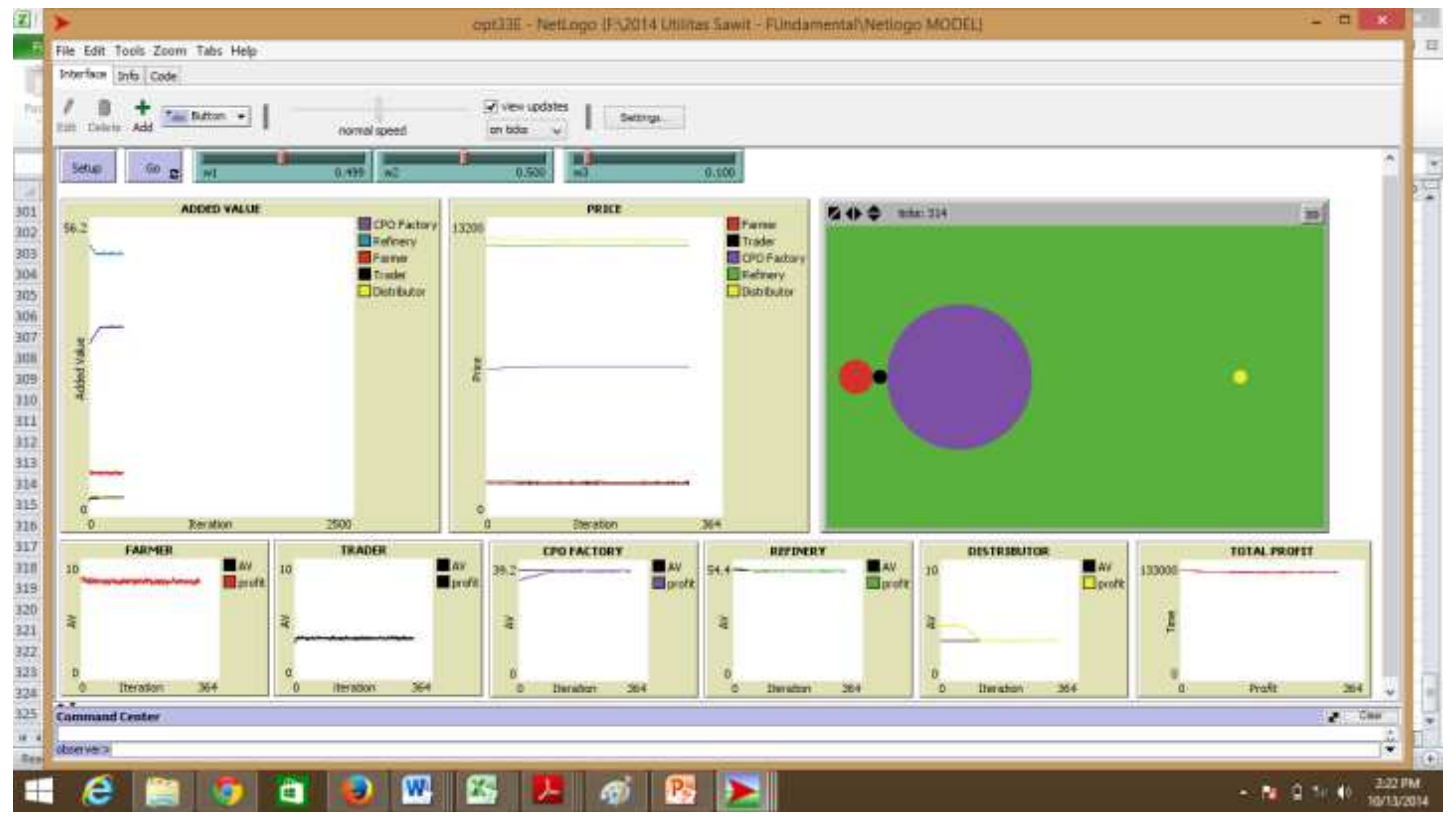

Figure 7. The Netlogo output after the negotiation cycle.

The result of running Optimization Netlogo Model using these weight levels is shown in Table 5. The table shows the gradual increase in the main products being sold along the POSC. Selling prices before the models were run appears on the first row, while the selling prices after the models were run (= "the should be prices") appear on the second row. The selling prices show increases for the farmers, traders and
CPO factory, but decreases for the refinery and the distributors. The total supply chain gain is reduced from $11,211 \mathrm{Rp} / \mathrm{kg}$ to $10,722 \mathrm{Rp} / \mathrm{kg}$. The highest profit is obtained by the refinery, CPO factory, group of farmers, traders, and the distributor respectively. Although the selling price is decreased, the refinery still gain the highest profit.

Table 5. The corresponding prices and profit ranks

\begin{tabular}{|c|c|c|c|c|c|c|}
\hline & & Farmer & Trader & CPO Factory & Refinery & Distributor \\
\hline Price (before) & $\mathrm{Rp} / \mathrm{kg}$ & 1,209 & 1,423 & 1,162 & 12,000 & 12,420 \\
\hline Price (after) & $\mathrm{Rp} / \mathrm{kg}$ & 1,397 & 1,500 & 6,753 & 11,889 & 12,119 \\
\hline Incr/Decr & & $16 \%$ & $5 \%$ & $481 \%$ & $-1 \%$ & $-2 \%$ \\
\hline Change & & 188 & 77 & 5,592 & (111) & (301) \\
\hline
\end{tabular}

\section{Conclusion}

This study has managed to provide a utility added value calculation computer model to obtain the maximum total added value and for each of the POSC actors. The utility model was a function of the risk, investment and technology levels of each actor. The algorithm used to obtain maximum value of the utility added value was based on the mathematical permutation of the risk, investment and technology factors, while changing the and weight levels in iteration. While the factual figures might be different considerably between the actors, we need to normalize their figures to come up with feasible results. The business levels among the POSC actors must be maintained to have fair flow of materials as well as money. The balancing process was initiated by optimizing the added value utility of each actor, while considering the overall POSC business continuity.

The study indicated that the negotiation between all actors in POSC need to consider overall supply chain sustainability 
while conducting pairwise negotiation. Otherwise overall sustainability of the supply chain may be endangered.

Many of the figures and values of the model were taken from different sources and they might not represent the real life values. The model still need to be tested to have a valid value in real life.

The model may be extended to be used for other commodity and different supply chain model with some adjustments in the profitability calculation formula. The model may also be extended to cover the most upstream of the POSC namely the palm oil seed industry. The secondary downstream industry may also include other products such as margarine, soap, vitamin $\mathrm{E}$ and many other palm oil based products.

\section{Acknowledgements}

The authors would like to express their gratitude to the Higher Education General Directorate of the Education and Culture Ministry of the Republic of Indonesia for providing the financial support for the study.

\section{References}

[1] P.V. Preckel, A. Gray, M. Boehlje, and S. Kim, "Risk and value chains: Participant sharing of risk and rewards". Journal on Chain and Network Services. 4(1), pp. 25-32. 2004.

[2] J.G.A.J. Van der Vorst, "Supply Chain Management: Theory and Practices. The Emerging World of Chains \& Networks", Elsevier, Hoofdstuk 2.1. Wageningen. 2004F. Bunte, "Pricing and Performance in Agri-Food Supply Chains First Edition"; 37-45. LEI, Wageningen University and Research Centre. Wageningen. 2006.

[3] A.M. Janvier-James, "A New Introduction to Supply Chains and Supply Chain Management: Definitions and Theories Perspective". International Business Research Journal. 5(1), pp. 194-207. 2012.

[4] J.H. Trienekens, "Agricultural Value Chains in Developing Countries ; A Framework for Analysis". Journal of International Food and Agribusiness Management Review. 14(2), pp. 51-82. 2011.

[5] [PKPN] Pusat Kebijakan Pendapatan Negara, "Kebijakan Restrukturisasi Tarif Bea Keluar Atas Kelapa Sawit, Minyak Sawit dan Produk Turunannya". Badan Kebijakan Fiskal, Kementerian Keuangan. Jakarta. 2011.

[6] [CAO] Compliance Advisor / Ombudsman. "LAPORAN AUDIT Audit CAO atas IFC. C-I-R6-Y08-F096". International Finance Corporation (IFC). Multilateral Investment Guarantee Agency (MIGA). Anggota Grup Bank Dunia. 2009.

[7] A. Mulyana, "Penetapan Harga Tandan Buah Segar Kelapa Sawit di Sumatera Selatan Dari Perspektif Pasar Monopoli Bilateral". Jurusan Sosial Ekonomi PertanianFakultas
Pertanian dan Program Pascasarjana Universitas Sriwijaya. Palembang. 2004.

[8] D. Coltrain, D. Barton, M. Boland, "Value Added: Opportunities And Strategies. Arthur Capper Cooperative Center". Department of Agricultural Economics. Kansas State University. Kansas City. 2000.

[9] T. Hines, "Supply Chain Strategies: Customer-driven and Customer-Focused". Great Britain. Elsevier Butterworth. Heinemann. 2004.

[10] E. Harjanto, "Manajemen Produksi dan Operasi Edisi 2". BPFE. Yogyakarta. 1999.

[11] W. Li, and Z. Yuanyuan, "A Game Analysis on Profit Distribution of Two-echelon Supply Chain with Principal and Subordinate". School of Economics and Management, Jiangsu University of Science \& Technology. Jiangsu. 2005.

[12] Bunte, F. "Pricing And Performance In Agri-Food Supply Chains First Edition"; 37-45. LEI, Wageningen University and Research Centre. Wageningen. 2006.

[13] D. Salvatore, "Managerial Economics in a Global Economy with Economic Applications Card", 5th edition. SouthWestern. ISBN/ISSN :0-324-17187-0. Copenhagen. 2004.

[14] A.K. Goel, S.L. Gupta, S. Srinivasan, and B.K. Bha, "Integration of Supply Chain Management Using Multiagent System \& Negotiation Model". International Journal of Computer and Electrical Engineering, 3(3), pp 375-378. 2011.

[15] T.S. Atkin, and L.M. Rinehart, "Effect of Negotiation Practices on Suppliers and Customers". Negotiation Journal January 2006. pp 47-65. 2006

[16] B. Palazzo, "An Introduction to Stakeholder Dialogue, Responsible Business" How to manage a CSR strategy successfully. John Wiley and Son; 17-42. Oxford. 2010.

[17] T. Juster, "Rethinking Utility Theory". The Journal of Behavioral Economics, JAI Press Inc., vol. 19, Number 2, pp. 155-179, 1990.

[18] S. Hidayat, Marimin, A. Suryani, Sukardi, and M. Yani, "Model Penyeimbangan Nilai Tambah Berdasarkan Tingkat Risiko Pada Rantai Pasok Minyak Sawit". PhD Thesis, Bogor Agricultural University (IPB). 2012.

[19] Suharjito, "Pemodelan Sistem Pendukung Pengambilan Keputusan Cerdas Manajemen Risiko Rantai Pasok Produksi/Komoditi Jagung”. PhD Thesis, Bogor Agricultural University (IPB). 2011.

[20] S. Awal, "Strategi Penyediaan Karbohidrat Bersumber dari Ubi Kayu". PhD Thesis . Bogor Agricultural University (IPB). 2012.

[21] M. Wooldridge, and N.R. Jennings, "Intelligent agents : theory and practice". Knowledge Engineering Review 10. London. 1995

[22] S. Tisue, and U. Wilenski, "NetLogo: Design and Implementation of a Multi-Agent Modeling Environment". Center for Connected Learning and Computer-Based Modeling Northwestern University, Evanston, Illinois. 2006. 